\title{
Spectroscopy, colorimetry, and biological chemistry in the nineteenth century
}

\author{
MG RINSLER \\ From the Department of Clinical Chemistry, Northwick Park Hospital, Watford Road, Harrow, \\ Middlesex $H A 13 U J, U K$
}

SUMMARY The development of colorimetry and spectroscopy in the nineteenth century is described. An account is given of the application of their techniques to biological chemistry during that period.

The development of the spectroscope in the nineteenth century

On 19 November 1859, Carl von Steinheil recorded in his diary that Robert Bunsen and Gustav Kirchhoff had visited him in Munich to ask him to make for them a large apparatus to examine the 'fixed lines' of the solar spectrum. ${ }^{1}$ It was only a matter of weeks (20 October) since they had announced at the Royal Prussian Academy of Science in Berlin their new analytical technique which was to lead to the discovery of caesium in 1861 and of rubidium soon after. For Bunsen (1811-99), professor of chemistry at Heidelberg since 1852, 'spectrum analysis' was a new tool that had a history longer, probably, than he was aware of; for Kirchhoff (1824-77), who joined Bunsen at Heidelberg in 1854, 'spectrum analysis' opened a new avenue of speculation concerning the nature of the stars and planets, based on his observations of the absorption and emission spectra of certain metals.

The story goes back to Isaac Newton (1642-1727), who published his observations on the spectrum and the nature of light in 1704, to William Hyde Wollaston (1766-1828), and to Joseph von Fraunhofer (1787-1826). Fraunhofer constructed the first spectroscope by replacing the mirror of a theodolite with a hollow prism, and gave his name to the 'fixed lines' of the solar spectrum described in 1814, which Wollaston had observed earlier, in 1802 , but which Newton had been unable to detect.

The early papers of Bunsen and Kirchhoff seem to have captured the imagination of scientists in many fields, not least in Great Britain, where workers such as Herschel, Brewster, Fox-Talbot, and Stokes had already made distinguished contributions with much simpler means. The new technique has to be seen against the scientific background of the time. One of the greatest influences on biological chemistry in the mid-nineteenth century was Justus von Liebig (1803-73). The methodology which he established was based on the identification and quantitation of well-characterised substances whose carbon, oxygen, and hydrogen content (and that of nitrogen, using the Dumas method) was known. Quantitation, for the most part, was gravimetric, with few instances of volumetric and occasional gasometric techniques. The formation of complex organic materials was poorly understood, and the nature of enzymes was just beginning to be studied, following the work of Claude Bernard and Anselme Payen in France.

The design of the spectroscope evolved rapidly once it was in Steinheil's hands from what appears to have been a rather primitive laboratory-built machine described in the first papers by Bunsen and Kirchhoff, to the two instruments which, on the evidence of the Steinheil catalogue of 1894, were to remain little changed for many years.

One of the best preserved spectroscopes based on the original design of Bunsen and Kirchhoff belonged to Charles Daubeny, professor of chemistry and botany in Oxford between 1822 and 1867; it is now in the Museum of the History of Science, Oxford. Interested as Daubeny was in the agricultural applications of chemistry, it is difficult to see for what purposes he intended to use his spectroscope, and he does not seem to have published papers which involved its use. We are not even certain where or when it was built, though it was rebuilt by Elliotts of the Strand, London, in 1903.

The use of spectroscopic techniques to identify biological materials was predicted by George Gabriel Stokes (1819-1903), an experimental physicist who occupied Newton's chair at Cambridge, in his paper of 1852 'On the change of refrangibility of light', in which he introduced the term 'fluorescence'. He noted the absorption pattern of chlorophyll and suggested that the identification of the spectrum 'might apparently be used as a chemical test for chlorophyll'.2 Soon after Bunsen and Kirchhoff's publications, Ernst Felix Hoppe- 
Seyler (1825-95), a pupil of Liebig, who in his turn was to dominate German and, to a large extent, European biochemistry, began while he was professor of applied chemistry at Tübingen to study the absorption patterns of coloured substances in solution. He used a Steinheil spectroscope simply by placing a rectangular cuvette between the lightsource and the collimating telescope. ${ }^{3}$ An account of this work appeared in the first volume of HoppeSeyler's Handbook in 1867 and in subsequent editions, and this established the spectroscope as a serious analytical tool for the biological chemist.

Hoppe-Seyler's publication of the absorption spectrum of haemoglobin stimulated Stokes to speculate on the change in haemoglobin during its passage through the lungs:

'But it seemed to me to be a point of special interest to enquire whether we could imitate the change of colour of arterial into that of venous blood, on the supposition that it arises from reduction.'

He went on to demonstrate that reduction in the test-tube altered the absorption spectrum and that if the sample of reduced haemoglobin (which he called 'purple cruorine') were shaken in air, the reaction was reversed and the original absorption pattern of the oxidised form returned. ${ }^{4}$

The general reaction of biological scientists in Europe was to concentrate on mapping the absorption spectra of naturally occurring coloured substances in normal and diseased states in the plant world, in animals, and in the human. Some of the outstanding contributions in this field were made in Great Britain by two physicians, JLW Thudicum and Charles MacMunn. Thudicum recorded in the Reports of the Medical Officer of the Privy Council, in the Proceedings of the Royal Society, and in other journals detailed studies of the yellow pigments in normal urine and other body fluids which he called 'luteines' (after the corpus luteum) and which are known today as carotenoids. ${ }^{5}$ In 1867 Thudicum accidentally produced the first known porphyrin (which he called 'cruentine') artificially from haemoglobin and observed its red fluorescence. ${ }^{6}$ MacMunn, in the late nineteenth century, made a study of abnormal pigments in urine, such as urobilin, and also established the spectrum of myoglobin in muscle, distinguishing it from circulating haemoglobin.?

Bunsen had pointed out that it was possible to use spectrum analysis quantitatively by dilution of the sample and comparison with standards. It is, therefore, not surprising that some scientists turned to the problems of quantitation of coloured substances in solution, a method that promised to be less tedious that the gravimetric methods in current use, particularly when one wished to apply chemical analysis to clinical problems. Choosing a unique band in the absorption spectrum gave the method an element of specificity. Beer had published his data concerning the transmission of light by coloured solutions before Bunsen and Kirchhoff's report on spectrum analysis. ${ }^{8}$ Bunsen with Roscoe had also established the principle of extinction coefficient in chemical analysis, using Bunsen's photometer. ${ }^{9}$

The description of what must be the first spectrophotometer appears in two remarkable volumes by Karl Vierordt, in which he details the results he obtained with it on measuring haemoglobin in blood (in health and in disease) as well as other materials in blood and urine. ${ }^{1011}$ Vierordt was professor of physiology at Tübingen while HoppeSeyler was working there. He fitted to a standard Steinheil spectroscope a double collimator with measuring devices which could estimate the rotation of each of the screws used to adjust the width of the slit. Through the viewing telescope the selected absorption band was studied simultaneously in respect of the unknown and the standard solutions in cuvettes, and the slit-widths were adjusted until the intensity of each was similar. By comparing the rotation of the screws, the concentration of the unknown could be determined by simple calculation.

Vierordt's instrument remained for many years the standard, with one or two variations. In Paris in 1888, d'Arsonval presented a spectrophotometer based on Vierordt's design and made by Pellin, Jules Duboscq's partner, which he used to measure haemoglobin. ${ }^{12}$ This instrument incorporated some of the optics of Duboscq's colorimeter and an adjustable collimator which was simpler to operate. It also incorporated an iris diaphragm adapted from a photometer designed by Charpentier. Considerable skill was required to set up instruments of this type and they suffered from a lack of linearity of response in relation to varying concentration. This failure to obey Beer's Law using biological samples was almost certainly due to the presence of substances other than that under study, which also absorbed at the wavelengths chosen, and to the alteration in response by changing the slit-width.

We have seen that much effort was concentrated, not unexpectedly, on substances that in solution were themselves coloured. Soret, in $1890,{ }^{13}$ began to examine the absorption patterns of materials that were colourless in solution. In particular, he examined the absorption patterns of fatty acids, ketones, and ethers using ultraviolet-rich sources of incident light. These studies were to extend considerably the use of spectroscopic techniques for the analysis of biological materials. By the end of the 
nineteenth century the spectroscope was established as an important qualitative tool in biochemical laboratories. With the introduction of colorimetric methods in which the coloured solution was the product of a chemical reaction, the limitations of the Vierordt type of spectrophotometer became apparent. The practicality, ease of operation, and precision of the simpler colorimeter had obvious advantages, and it replaced the spectrophotometer for quantitative purposes, particularly as the results of research led to the establishment of service laboratories.

\section{Colorimetry before Duboscq}

The need for matching and measuring the intensity of coloured solutions is probably as old as the dyeing industry and wine manufacture. Probably the first colorimeter was designed by HoutouLabillardière for the measurement of indigo in solution. ${ }^{14}$ It was a simple comparator using two calibrated tubes, one for the standard and the other for the unknown solution, which was diluted until the colours matched visually in a light-transmitting box.

Problems in the refining of sugar at about this time were to have a close link with this event. In the eighteenth century, the world sugar industry had been centred in the West Indian colonies of France, Britain, and Spain. The naval blockade of France at the beginning of the nineteenth century led to the stimulation by Napoleon of sugar manufacture from sugar beet in France. Caramelisation of some of the sugar during its extraction gave the final product a dirty-brown colour. Heating with activated animal carbon removed these impurities, but the activity of the carbon preparations varied. Anselme Payen (1795-1871), one of the giants of industrial chemistry in nineteenth-century France, was a member of the same scientific academy in Rouen as HoutouLabillardière, and it is likely that he heard his paper or saw the publication. Soon after, he applied the colorimetric principle to the measurement of the decolorising activity of bone-carbons. ${ }^{15}$ Payen passed his ideas to Collardeau, a scientific instrument manufacturer, who produced in 1838 a twin-tube colorimeter in which a standard solution could be compared with the one to be tested. ${ }^{16}$ The depth of the solution in each tube could be varied by pushing a calibrated tube with a glass window in or out of the sample tube (or the standard) in the manner of a telescope until the two images matched. It could not have been a very convenient instrument to use. This instrument and that of HoutouLabillardière were to be the usual means of colorimetry in the dyeing and sugar industries for 30 years, both appearing in J Salleron's catalogue in 1861.

A number of colorimeters were designed in Germany during a similar period, of which the most interesting is that mentioned in a paper by $\mathrm{J}$ Dehms and manufactured by Siemans and Halske. ${ }^{17}$ Based on a plunger mechanism, which varied the depth of the coloured solution to be examined, it was constructed in a rather primitive fashion of tin with plain glass apertures. Because it employed only one tube, the standard and unknown could not be compared in a simultaneous operation.

\section{The Duboscq colorimeter}

Jules Duboscq was born in 1816 in France, where he died in 1886. He worked for J-B Soleil, a well-known optical instrument manufacturer in Paris, married his daughter, and eventually succeeded him. Soleil designed and made machines for many distinguished physicists including Masson, Babinet, and Regnault. $\mathrm{He}$ is best known for his saccharimeter. We may suppose that Duboscq, working on these instruments for Soleil, became interested in the problems of colorimetry and spectroscopy. He was the first to manufacture and modify the Steinheil spectroscope in France after the publication of the papers by Bunsen and Kirchhoff in 1859 and 1860 . Duboscq continued to use Soleil's shop in the rue de l'Odéon, though he seems to have shared the premises with other members of the family, principally Léon Laurent. The rue de l'Odéon is a short walk from the university, the Collège de France, and the medical school where most of his customers worked. The firm was one of the most distinguished optical instrument manufacturers in France and exhibited regularly at international exhibitions (including the Great Exhibition in London, 1851), obtaining numerous gold medals.

Ph. Pellin, who took over the Duboscq business, tells us in his annotated catalogue in 1898 that Duboscq invented his colorimeter in 1854.18 It appeared in the Duboscq catalogue of 1876, but little is heard of it before 1868. In this year, Charles Mène, an industrial chemist and editor, introduced the instrument to the Académie des Sciences and published a full account of it in his own journal. 1920 This information was reported in the issue of Chemical News for 21 January 1870, and in the Zeitschrift für analytische Chemie in the same year.

The instrument had a number of interesting features apart from the usual excellence of Duboscq manufacture. The cups were of high-quality glass or quartz, and the light was transmitted in a highly original way via glass plungers and a pair of Fresnel parallelipipedes so that a pair of images could be 
viewed through a telescope containing a suitable lens train. The intensity of standard and unknown were compared with one eye. The calibrated racking enabled the plunger to be raised and lowered easily until a satisfactory match was obtained.

Prints from the original blocks from Ch. Mène's review appeared in a number of journals, in Pellin's catalogues and, after the turn of the century, in numerous editions from 1910 onwards of Hawk's Practical Physiological Chemistry, which helped eventually to spread the fame of this instrument 50 years after its invention.

There was a major variant of the Duboscq instrument, which was manufactured by Léon Laurent. Laurent himself is best known for a very good saccharimeter. He was either a nephew or a grandson of Soleil and does not appear to have been on very good terms with Jules Duboscq. The major modifications concerned the light transmission and the eyepiece, as well as the tracking mechanism for raising or lowering the glass plungers. Pellin himself modified the colorimeter by fitting longer plungers and adding a cover to exclude stray light from the plungers and cells. Numerous other instrument manufacturers in Europe and the United States of America produced copies or variants of the instrument in the first half of the twentieth century, including Klett and Leitz.

Colorimetric methods for copper, chromium, and nickel, depending on the formation of a coloured product in solution, were introduced slowly after 1830. Eggertz, an eminent Swedish chemist, proposed colorimetric methods for measuring iron in 1862, and for bicarbonate in steel in 1863 , by visual inspection and dilution. These methods were reviewed in Ch. Mène's journal shortly after Duboscq's colorimeter was described in 1868, and it seems that some industrial laboratories adapted them to the colorimeter. ${ }^{21}$

The first use of the Duboscq colorimeter in biological chemistry appears to have been by Jolyet and Laffont, working in Paris. They wished to measure the respiratory capacity of the blood in dogs, which entailed blood haemoglobin measurements. ${ }^{22}$ Though they demonstrated the precision of the instrument, clinical haematologists and, in particular, Hayem ${ }^{23}$ frowned on the machine because it required the use of a relatively large sample and produced problems in standardisation. Hayem preferred the simple dilution haemoglobinometers such as that designed by Hénocque, in which the diluted sample was compared by visual means with a fixed standard and which required only capillary sampling. Venepuncture for sample collection was not a routine procedure at the time.

There is an interval before the next mention of the Duboscq colorimeter in relation to biological measurements. Lapique, who was to succeed to Claude Bernard's chair at the Jardin des Plantes, used Duboscq's instrument for measuring iron as ferric sulphocyanide in biological materials, a procedure based on Eggertz's method. ${ }^{24}$ We then have to wait until 1895 for a further extension of the use of colorimetry. In the Report of the Municipal Observatory of Paris for that year, Lévy notes the \& use of a Duboscq colorimeter in the measurement of $\overrightarrow{0}$ ammonia in the air, based on the Nessler method. ${ }^{25}$ His instrument, one of the few remaining examples $\vec{\omega}$ made by Duboscq and Pellin, was still in use in $\frac{\Omega}{\partial}$ the Hygiene Laboratory of Paris until about 15 ? years ago. The distinguished sugar chemist, $\stackrel{\omega}{\oplus}$ Sidersky, ${ }^{26}$ used a Duboscq instrument to measure $\omega$ sugar by a copper reduction method. It is not until $\underset{\sim}{N}$ 1904 that we come to Otto Folin's classical method for the measurement of creatinine and creatine in $\frac{5}{5}$ urine based on the Jaffé reaction and using a $\vec{z}$ Duboscq colorimeter. ${ }^{27}$ Published in a journal widely read by biological chemists, this proved to be the $\frac{\hat{S}}{\mathcal{S}}$ watershed for colorimetry as a basic scientific technique.

Goudsmit and Summerson ${ }^{28}$ attached two photoelectric cells to a Duboscq-type colorimeter, using a common light source reversing the light transmission. Provision was made 'for simultaneous comparison of standard and unknown against each other and for independently varying the depth of layer of each solution'. The authors were of the opinion that this original feature of the Duboscq instrument was an advantage 'in contrast to other instruments . . . (as) ... a an accessory compensating mechanism such as an adjustable diaphragm or a variable resistance' was not required. This was the last significant application of the plunger-type colorimeter. The trend was already established for fixed-length light paths. ${ }^{29}$

It is of interest to compare the Duboscq instrument with the Pulfrich colorimeter developed at the $\frac{9}{5}$ beginning of the twentieth century and manufactured $\frac{D}{0}$ by Carl Zeiss, which dominated the German colorimetric scene as Duboscq's instrument did the N French, British, and American in the first 40 or 50 years of this century. Pulfrich's solution to the problem of varying transmission was to use variable $\omega$ calibrated apertures (an idea that Duboscq had incorporated into his photometer designed with 0 Parinaud ${ }^{30}$ ) and to set his instrument in a horizontal plane, allowing the use of sample cells of fixed but? differing path lengths. He also used Fresnel parallelipipedes, as did Duboscq.

Jules Duboscq spans the use of the colorimeter $\stackrel{\square}{\Omega}$ from the early days of the dyeing and sugar industries $\stackrel{\square}{\square}$ to the introduction of the photoelectric colorimeter. 
Little appreciated for its contribution to colorimetry in his own time, his novel instrument has been a mainstay for many generations of biological chemists from 1890 to 1950 . Quantitative emission spectroscopy was not a practical technique in the nineteenth century, although it was used by Bunsen himself to measure the concentration in solution of the metals that he discovered. The full potential of both the absorption spectrophotometer and the colorimeter as analytical instruments was not to be realised until relatively stable electric-light sources and the photoelectric cell became commercially available in the twentieth century.

\section{References}

1 von Steinheil C. Diary (unpublished). In possession of Deutsches Museum, Munich.

${ }^{2}$ Stokes GG. On the change of refrangibility of light. Philos Trans $R$ Soc Lond 1852;142:463-562.

${ }^{3}$ Hoppe F. Ueber das Verhalten des Blutfarbstoffes im Spectrum des Sonnenlichtes. Virchows Arch 1862;23: 446-51.

${ }^{4}$ Stokes GG. On the reduction and oxidation of the colouring matter of the blood. Proc Roy Soc Lond 1864;13: 355-64.

5 Thudicum JLW. Report of the Medical Officer of the Privy Council 1868;11:Appendix 6, 184.

- Thudicum JLW. Report of the Medical Officer of the Privy Council 1867;10:Appendix 7, 227.

7 MacMunn C. VI Researches on myohaematin and the histohaematins. Philos Trans $R$ Soc Lond 1886;177:26798.

${ }^{8}$ Beer A. III Bestimmung der Absorbtion des rothen Lichts in farbigen Flüssigkeiten. Annalen der Physik und Chemie (Poggendorf) 1852;86:78-90.

${ }^{9}$ Bunsen R, Roscoe H. IV Photochemische Untersuchungen. Annalen der Physik und Chemie (Poggendorf) 1857;13: 235-63.

${ }^{10}$ Vierordt K. Die Anwendung des Spektralapparates zur Photometrie der Absorbtionsspectren und zur quantitativen chemischen Analyse. Tübingen: 1873.

11 Vierordt K. Die quantitative Spektralanalyse in ihrer Anwendung auf Physiologie, Physik, Chemie und Technologie. Tübingen: 1876.

12 d'Arsonval A. Sur un spectro-photomètre nouveau. $C R$ Soc Biol (Paris) 1888;40:800-3.

${ }^{13}$ Soret JL, Rilliet A. Sur l'absorption des rayons ultra- violets par quelques substances organiques faisant partie de la série grasse. C R Acad Sci (Paris) 1890; 110:137-9.

${ }^{14}$ Houtou-Labillardière JJ. Description d'un colorimètre. Extrait des actes de l'Académie Royale des Sciences, Belles-Lettres et Arts de Rouen. Rouen: 1827.

15 Payen A, et al. Résumé du cours pratique de fabrication du sucre indigène. Paris: $1838 ; 92$.

${ }^{16}$ Collardeau, F. Description d'un colorimètre à double lunette. Bulletin de la Société d'Encouragement pour l'Industrie nationale 1838;37:54-8.

17 Dehms J. Über colorimetrische Analyse. Dinglers Polytechnisches Journal 1864;172:440-4.

${ }_{18}$ Pellin Ph. Instruments d'optique et de précision. Paris: 1898.

19 Mène Ch. Le colorimètre par M. Duboscq. Revue Hebdomadaire de Chimie Scientifique et Industrielle $1868 ; 1: 99-101$.

${ }^{20}$ Duboscq $\mathrm{J}$, Mène $\mathrm{Ch}$. Nouveau colorimètre pour l'analyse des matières tinctoriales au point de vue commercial. C R Acad Sci (Paris) 1868;67:1330-1.

${ }^{21}$ Mène $\mathrm{Ch}$. Nouvelles méthodes analytiques des fontes et aciers par M. le professeur Eggertz de Fahlum (Suède). Revue Hebdomadaire de Chimie Scientifique et Industrielle 1869;1:49.

22 Jolyet $F$, Laffont $M$. Recherches sur la quantité et la capacité respiratoire du sang par la méthode colorimétrique. C R Soc Biol (Paris) 1877;39:151-2.

${ }^{23}$ Hayem G. Report of discussion. $C R$ Soc Biol (Paris) 1877;39:299-301.

${ }^{24}$ Lapique L. Sur le dosage colorimétrique du fer. $C R$ Soc Biol (Paris) 1890;42:669-71.

${ }^{25}$ Lévy A, Marboutin F. Annuaire de l'observatoire municipal de Montsouris pour l'année 1895. Paris: 1895;291.

${ }^{26}$ Sidersky D. Traité d'analyse de matières sucrées. Paris: $1890 ; 370$.

${ }^{27}$ Folin O. Beitrag zur Chemie des Kreatinins und Kreatins im Harne. Hoppe-Seylers Z Physiol Chem 1904;41: 223-42.

${ }^{28}$ Goudsmit A, Summerson WH. A variable layer photoelectric comparison photometer. J Biol Chem 1935;111: 421-33.

29 Sheard C, Sandford AH. A photo-electric haemoglobinometer. J Lab Clin Med 1929;14:558-73.

${ }^{30}$ Parinaud $\mathrm{H}$, Duboscq J. Appareil destiné à l'étude des intensités lumineuse et chromatique des couleurs spectrales et de leurs mélanges. $J$ de Physique 1885;4: 271-3.

Requests for reprints to: Dr MG Rinsler, Department of Clinical Chemistry, Northwick Park Hospital, Watford Road, Harrow, Middlesex HA1 3UJ. 